\title{
Portrayal of Skilled Migrants' Careers in Business and Management Studies: A Review of the Literature and Future Research Agenda
}

\author{
Marian Crowley-Henry, ${ }^{1}$ Edward O' Connor $^{1}$ and Akram Al Ariss ${ }^{2}$ \\ ${ }^{1}$ Maynooth University School of Business, Maynooth, Ireland \\ ${ }^{2}$ Toulouse Business School, Université de Toulouse, Toulouse, France
}

\begin{abstract}
A systematic literature review in business and management studies was conducted, which paints a portrait of the existing literature on skilled migrants' host country career experiences. Core themes arising from this review are presented, including labeling inconsistency concerning the population (with researchers using terminology such as 'skilled migrants,' 'immigrant professionals' and 'qualified immigrants' interchangeably); the need for including skilled migrant managers and business professionals in research (rather than concentrating on lower-level employment categories only); and a more relational, holistic realization of skilled migrants' careers (rather than the current literature's negative portrayal, propounding the image of migrants as exploited or under-utilized). In underlining the gaps in the literature and research in this area, a research agenda is proposed. The review is relevant for individuals following careers in a foreign country; for organizations employing and developing the careers of internationally mobile employees; and for human resource management professionals supporting international employees.
\end{abstract}

Keywords: skilled migrant; career; systematic literature review; immigrant professional; qualified immigrant; selfinitiated expatriate

\section{Introduction}

In the last ten years, internationally mobile professionals beyond the organization-assigned expatriate are increasingly discussed in management and organization studies. International migrants, as one category of international labor inflows to countries, have been recognized as valuable human resources to organizations and countries (Syed \& Murray 2009; Al Ariss \& Syed 2011; Cerdin et al. 2014). Skilled migrants, for the purpose of this paper, are defined as having a university degree or extensive experience in a given field (Iredale 1999). Their potential contribution to organizations and countries is considerable with skilled migrants embodying a significant resource of skills that can alleviate or even solve skills shortages in specific sectors (Borjas 2001). Nevertheless, existing knowledge on skilled migrants'

Correspondence: Marian Crowley-Henry, Maynooth University School of Business (National University of Ireland Maynooth), Rye Hall Extension (north campus), Maynooth, Ireland, Tel: +353 1708 4756; Fax: +353

1628 6519. E-mail: marian.crowleyhenry@nuim.ie careers in management and organization-related studies requires synthesis, consideration of gaps in the existing research, and direction towards future research opportunities. We attempt to contribute to this special issue by addressing each of these concerns in turn. Specifically, this paper paints a portrait of the existing literature on skilled migrants' careers in management studies. It shines a spotlight on the research gaps in this area and proposes a research agenda to tackle those research gaps.

A systematic literature review (SLR) (Tranfield et al. 2003; Petticrew \& Roberts 2006) was undertaken drawing on literature in the business and management domains. The next section details how this SLR was conducted facilitating replicability for other researchers. We balance the discussion on SLRs by both outlining the limitations of the SLR process and emphasizing its contribution to management research. Then we highlight, from our review, the main themes in the literature on skilled migrants in the business academic domain. We identify the gaps in the extant literature and, finally, suggest a research agenda. 
The primary contribution of this paper is for the benefit of management researchers in providing a synthesis of research themes on skilled migrants' careers in business and management studies. Second, for organizations, managers and human resource managers employing skilled migrants, the paper highlights the common challenges and benefits associated with this international labor population across the literature, and the organizational supports that may be required. Third, for skilled migrants, the paper unpacks from the detailed SLR the dynamic multilevel factors impacting on their workplace experiences and careers in a foreign country, providing researchers and practitioners alike with a better understanding of the consolidated facilitators and challenges skilled migrants face in their careers.

\section{Research approach: the systematic literature review}

The systematic literature review model (SLR) has been proposed as a useful research method in management studies in order to overcome the criticism that literature reviews in this area are deficient in evidence and rigor (Tranfield et al. 2003). Having attained popularity in the discipline of medicine, it is acknowledged that, when applied to management studies and social science literature, the SLR model relies largely on the subjective judgement and interpretation of the researcher(s), who determine the articles to ultimately include or exclude for particular reasons (Denyer \& Tranfield 2009). In this way, it is recognized that the SLR process is an iterative process, 'requiring researchers to engage with each stage in a reflexive way' (Arksey \& O'Malley 2005: 22). Below we explain how this was done for this paper.

The five steps in the SLR model are as follows (Pittaway et al. 2004; Denyer \& Tranfield 2009): (1) scoping study (identification of broad topics to be included; career and skilled migrant were the core topics in our search); (2) pilot testing search strings (in our case, the initial search was 'skilled migrant,' or 'migration' and 'career;' we subsequently added 'immigrant professional' or 'qualified immigrant' to the search strings); (3) categorizing results (determining if there is duplication or irrelevant results; this was the most iterative and timeconsuming of the filtering process, where the coauthors individually and collaboratively determined which articles were most relevant to the SLR analysis); (4) reviewing relevant articles/sources (reading remaining sources, including relevant articles in the references of those articles returned from the SLR); and finally, (5) synthesizing and critiquing relevant articles (in order to determine themes and gaps). While these steps appear linear, they are actually more reflexive in practice. For instance, in synthesizing and critiquing the relevant articles in our SLR (step 5 above), we discovered that articles on 'immigrant professionals' and 'qualified immigrants' were missing. In our analysis, both qualified immigrants and immigrant professionals are analogous with skilled migrants as an international labor category. This led to us refining our search strings (steps 1 and 2 above) to allow us to categorize and review those returns (steps 3 and 4).

The Web of Science database (including 2.6 million records, http://wokinfo.com/) was the repository searched for the SLR (cf. Özbilgin et al. 2011). Within the Web of Science database, the Social Sciences Citation Index (1956-present) was selected and all articles between 2000 and 2015 were searched. Our focus in this review was on recent research and literature on migrants' careers, so we limited the search to publications since 2000 (cf. Andresen et al. 2014).

We searched for articles which had in their topic 'career' and either 'migration,' or 'skilled migrant,' or 'qualified immigrant,' or 'immigrant professional.' The initial return (excluding qualified immigrant or immigrant professional) was 25,373 , which rose to 25,588 when we included those terms in the search string. We filtered out any non-English language articles which reduced the articles to 23,934 . We then refined the search to the single research area of Business and Economics, which reduced the returns to 4,128 articles. Next, we refined by two Web of Science categories: business and management, which resulted in 451 articles. We refined the search by document type and kept in only articles (not book reviews, or proceedings papers). This resulted in 406 articles remaining. Then we filtered out articles that were not published in general business and management journals. For instance, we excluded articles (called 'source titles' on the database) published in scientific or technological journals such as Science, Technology and Society and Information Systems Research, where migration referred to IT systems rather than the population of migrants being investigated in this review; and in marketing-specific journals such as Marketing Science and Advances in Marketing Research, where the focus was more on consumer migration. Our focus in the review was on publications in business and management peer-reviewed journals only, concerning career and where the population being studied was identified as skilled migrants, in line with the research focus in the scoping study (first stage in a SLR). This reduced the number of potential articles in the review to 217 (see Appendix 1 for the detailed search string).

Next, we focused on ABS-rated journals only (http:// charteredabs.org/academic-journal-guide-2015-view/), as a means of further filtering the journals and the corresponding articles to be reviewed, according to an objective quality ranking system. Articles published in ABS-ranked journals undergo a stringent peer-review process to meet quality expectations. This filtering of both 
non-relevant and non-ABS-ranked journals narrowed our search to 170 articles.

Next, we reviewed the titles of the articles in those journals, and if we were unclear from the titles whether or not the article would be relevant (that is, included content on migrants' careers in business and management studies), we read the article's abstract, removing from our review any articles which did not focus on our broad search topics of career and skilled migrants. The criteria we adopted was to consider if, from the abstract and the title, it was clear that the article concerned career or career-related topics, related to skilled non-host country nationals, that is, for skilled migrants/internationally mobile professionals. This is the 3rd step in the SLR approach - categorizing results and removing irrelevant returns. It is here that researcher discretion and the subjectivity of the researcher is paramount in making the judgement whether or not to include or exclude articles from the review (Denyer \& Tranfield 2009). The decision to exclude papers here was verified among the authors, thereby granting some element of rigor and reliability in the methodology of our exclusion criteria. It is an iterative process, filtering down articles until there was agreement amongst the authors that the remaining articles were relevant and required further analysis. In order to facilitate replicability of our process for other researchers, our process here was as follows: we individually went through each of the articles that were returned (their titles and abstracts) and selected those which we felt warranted inclusion in the SLR. Those lists were compared between all researchers, until the shortlisted 47 papers were reached. The questions we posed in determining which papers to exclude were: Is the article concerned with the population of interest, with the search string terms used in the article (migration or skilled migrant or immigrant professional or qualified immigrant)? Is the article concerned with the workplace careers of this population, or the workplace experiences of this population which would have an impact on their careers? Articles were excluded which concerned, for example, remittances, or welfare chasing, or domestic migration, or undocumented migrants, or economic migration flows, since our focus was on the careers of skilled migrants in the host country. This is the stage which underlines the researcher's role in the SLR and could be considered one limitation of the SLR process in business and management studies, where researcher subjectivity is used to determine exclusivity criteria to shortlist the articles in the review. This influences the replicability of SLRs across researchers in the business and management domain. However, we hope that our documentation of the process we undertook for this study will aid other researchers undertaking SLRs.

Each of the 47 remaining articles were reviewed, in line with step four of the SLR process, and then finally (step 5) categorized thematically and critiqued with regards to apparent research gaps in the area. While considering our returned articles from the SLR, we found that certain articles were missing. This was because some journals are not included in the Social Sciences Citation Index on the Web of Science database we were searching, notably the Journal of Management Development which had published a special issue on the careers of skilled migrants in 2013. This is a further limitation of database-specific SLRs in business and management studies, where not all journals are included on the search databases. We retrospectively included this journal in separate searches and added the relevant articles from the Journal of Management Development to this review $(n=5)$, bringing the total number of articles in this SLR to 52. Table 1 summarizes the articles that were included in the review and which form the basis of the discussion in the rest of the paper.

However, there may be other journals which were also excluded in our SLR. We recommend that future SLRs in this domain extend the search to include other databases with as wide a journal inclusion listing as possible in order to overcome this shortcoming. It would be interesting to compare such a study with the one conducted here in order to ascertain if the same common themes were apparent. This again underlines the importance of researcher discretion and reflexivity in practice when conducting a database-specific SLR. It also shows that SLRs in business and management studies are currently cumbersome in practice, but we hope that this will improve as more journals are affiliated with the main academic databases in time. SLRs, therefore, in practice are iterative and never final given the limitations of journals that may not be on particular databases, given the ongoing publications taking place which can render SLRs outdated after a short period of time, and given the researchers' judgement calls which ultimately determine which articles remain in the review or not. Nonetheless, SLRs do facilitate a pathway for replicable and comparative studies when the process followed is clearly delineated, as we have attempted to do above.

The abstracts and papers of all 52 articles were read and considered thematically. 'Synthesizing evidence is like assembling a jigsaw' (Petticrew \& Roberts 2006: 125), with the four preceding steps of the SLR being concerned with finding the right pieces. In this SLR, the analysis involved organizing the returned papers into groups of meta-themes and analyzing each paper's findings within its theme. To ensure thematic consistency and reliability, the coauthors reviewed the original themes put forward by the first author, which were then discussed until agreement was reached between all authors as to the core themes in the recent literature on migration/migrants and careers in business and management studies. The metatheme column in Table 1 presents how we categorized each paper under the themes we identified across the 


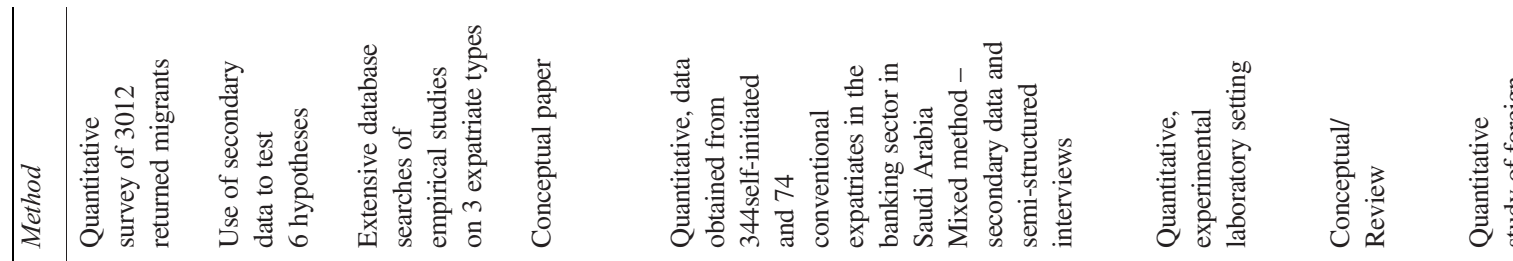
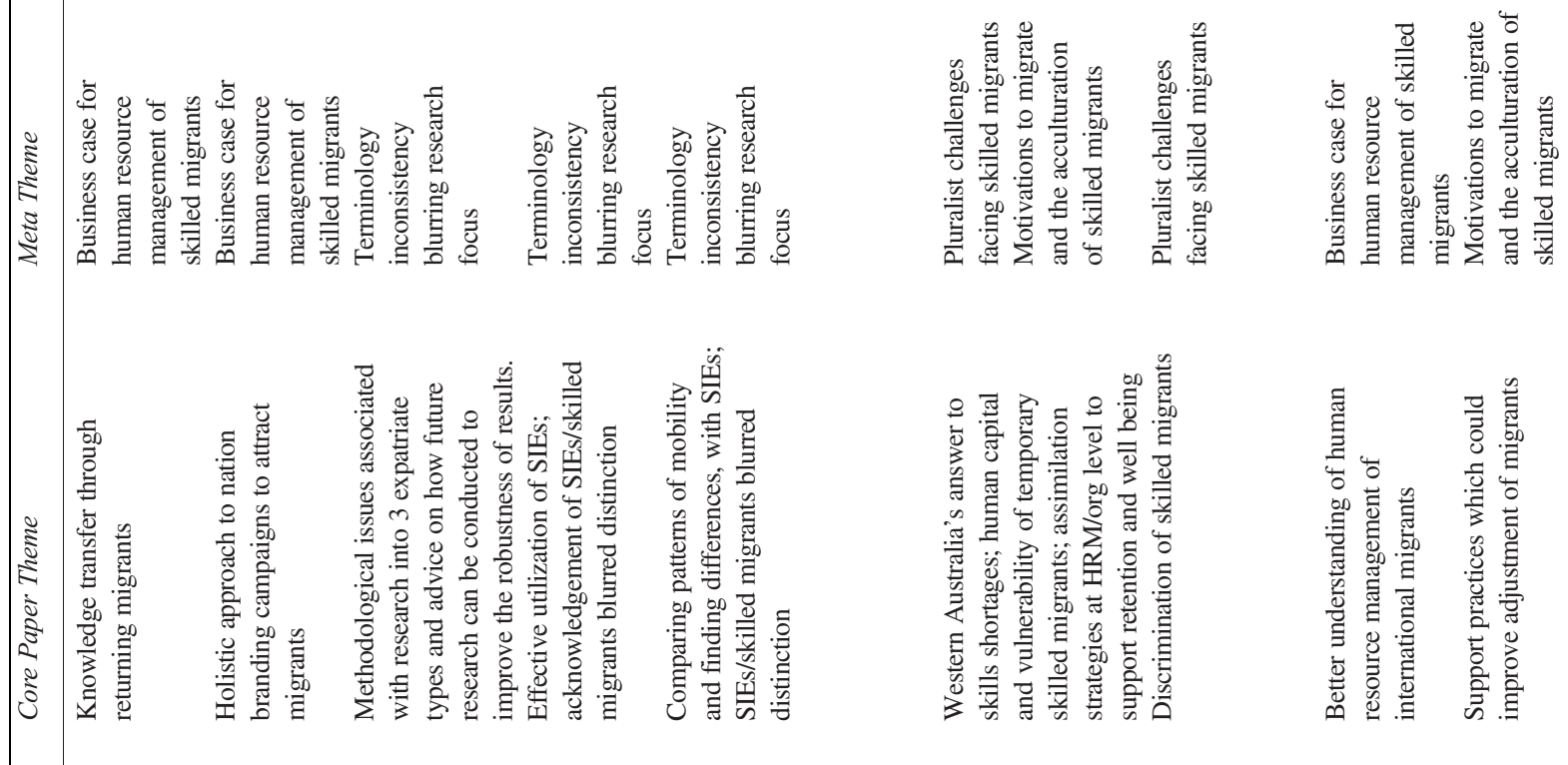

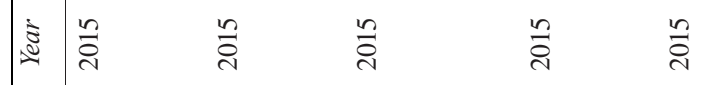

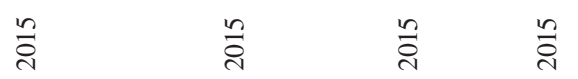

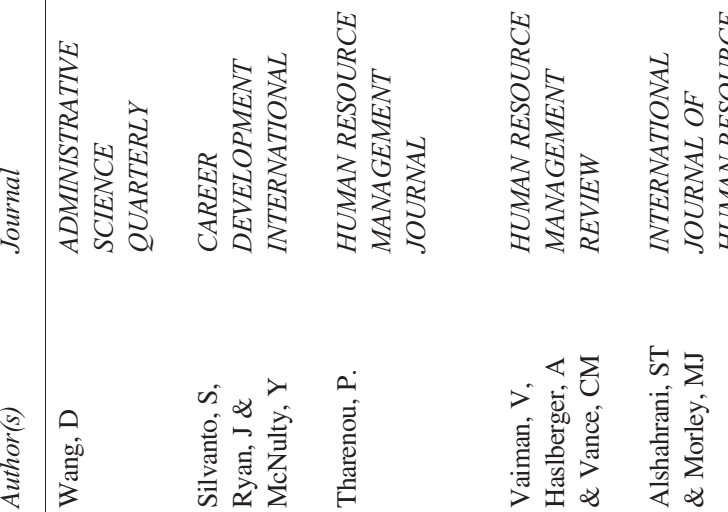

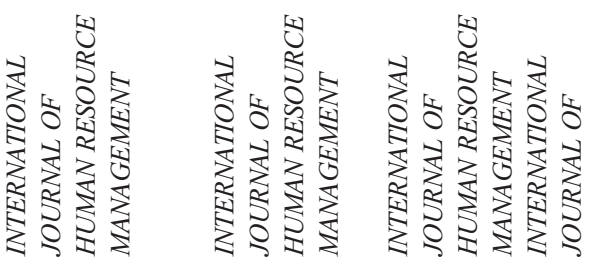

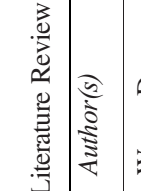

童

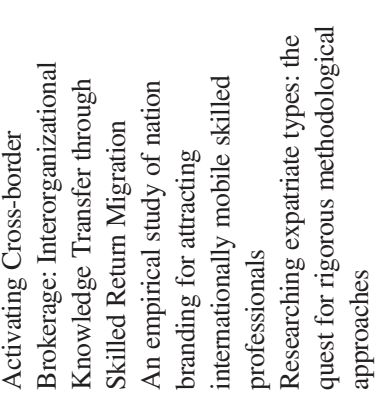

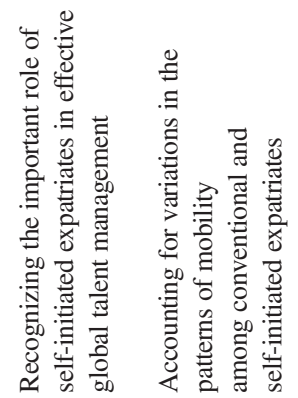

趈

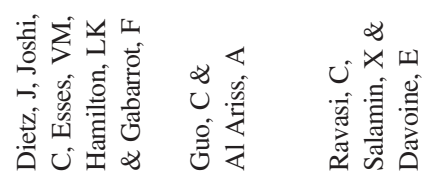
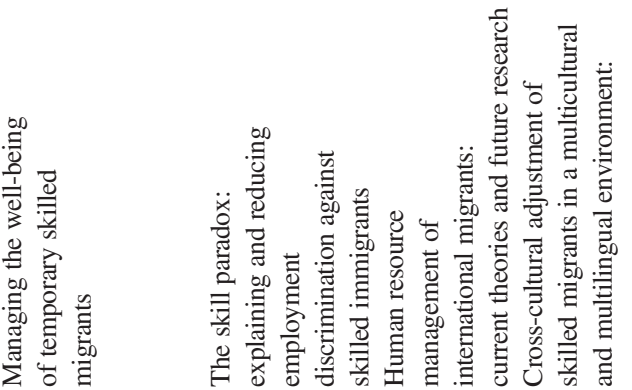


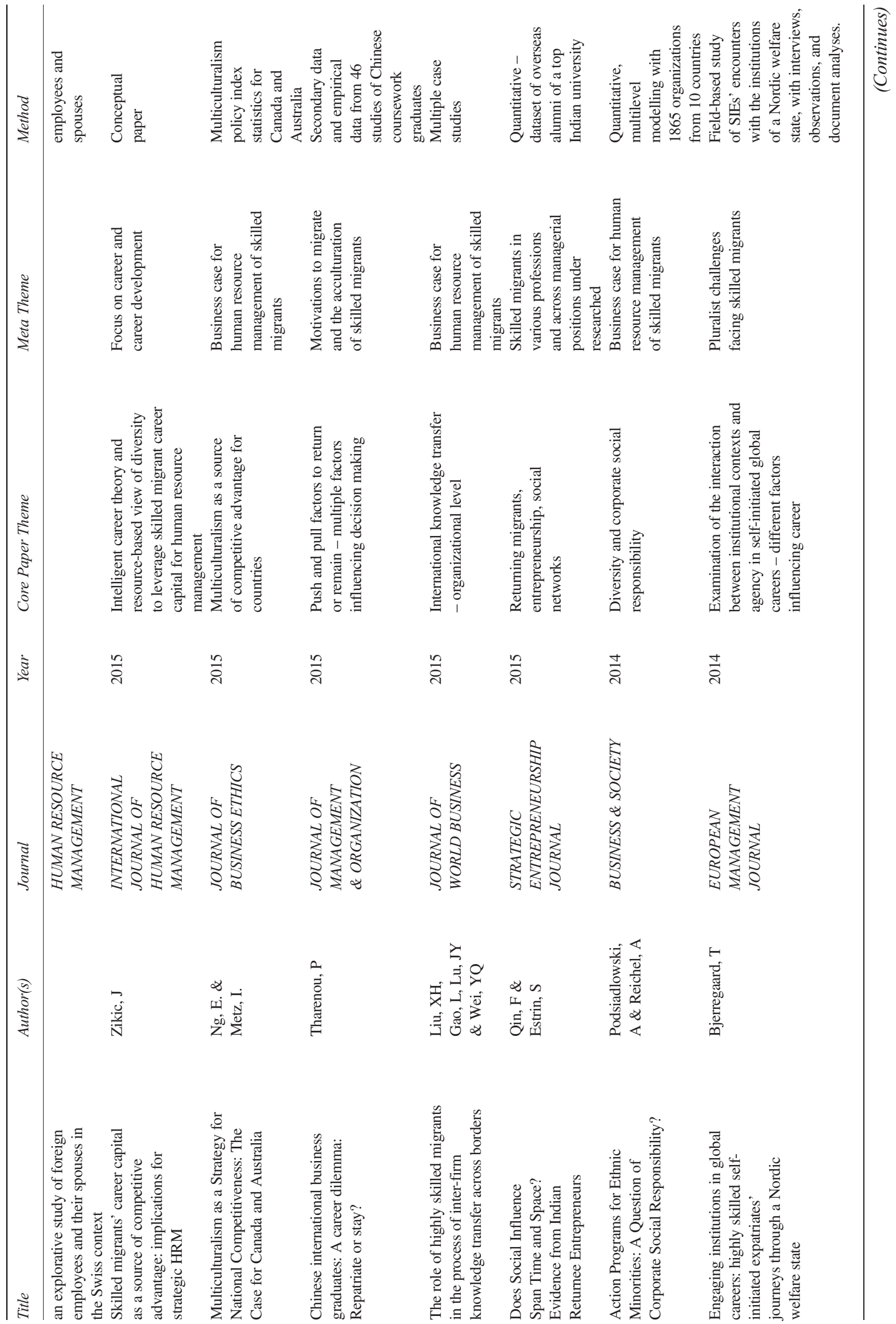




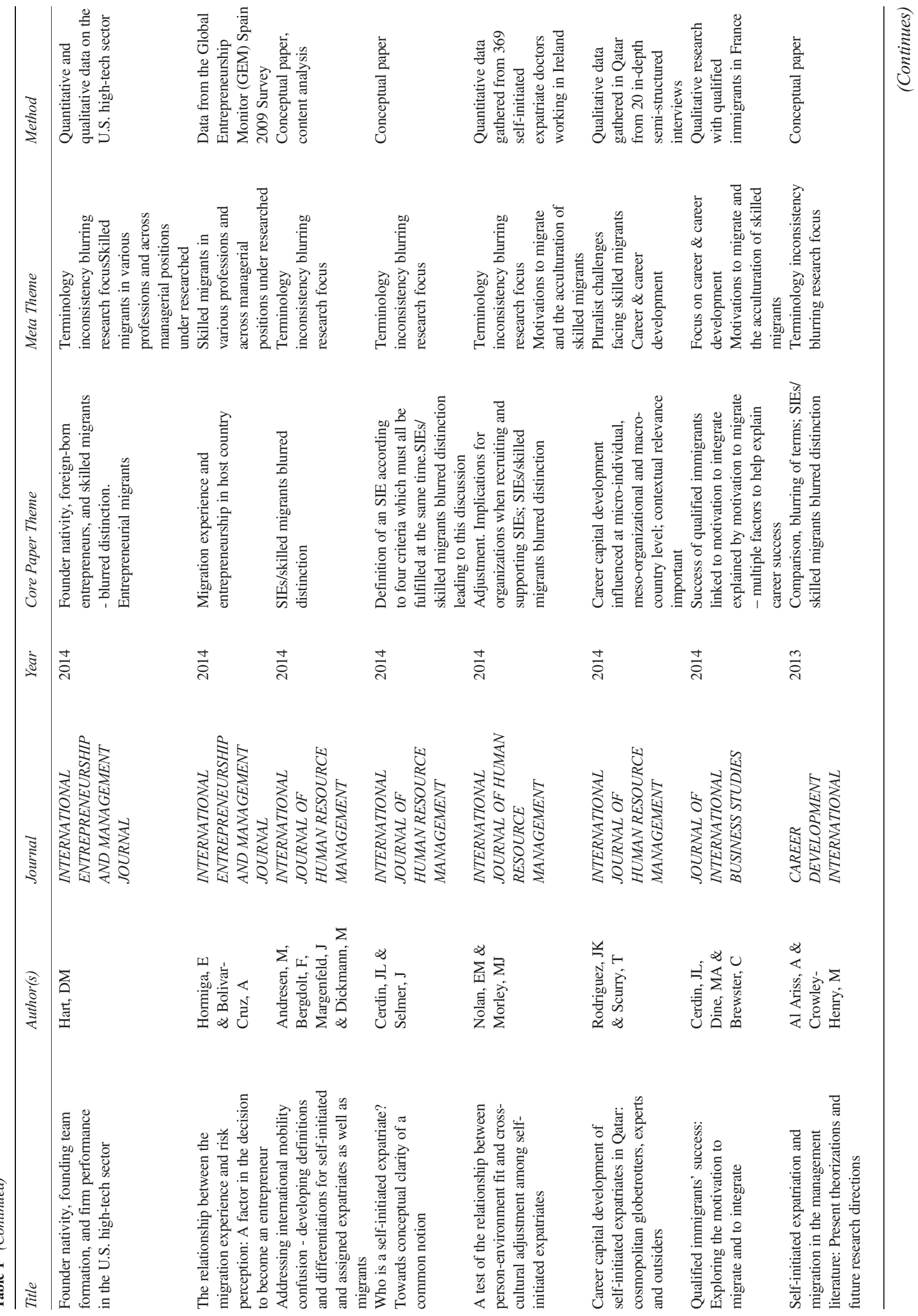




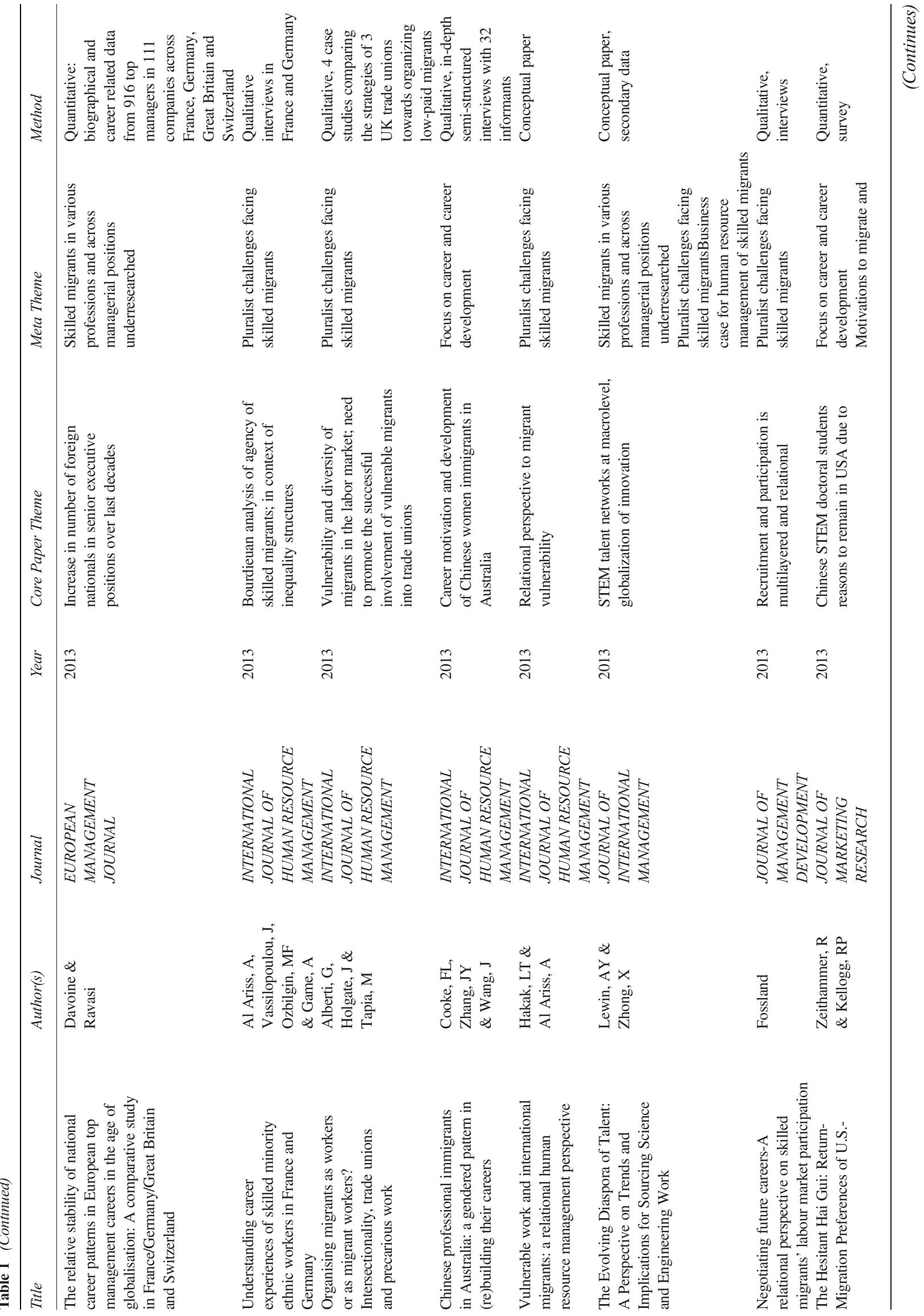




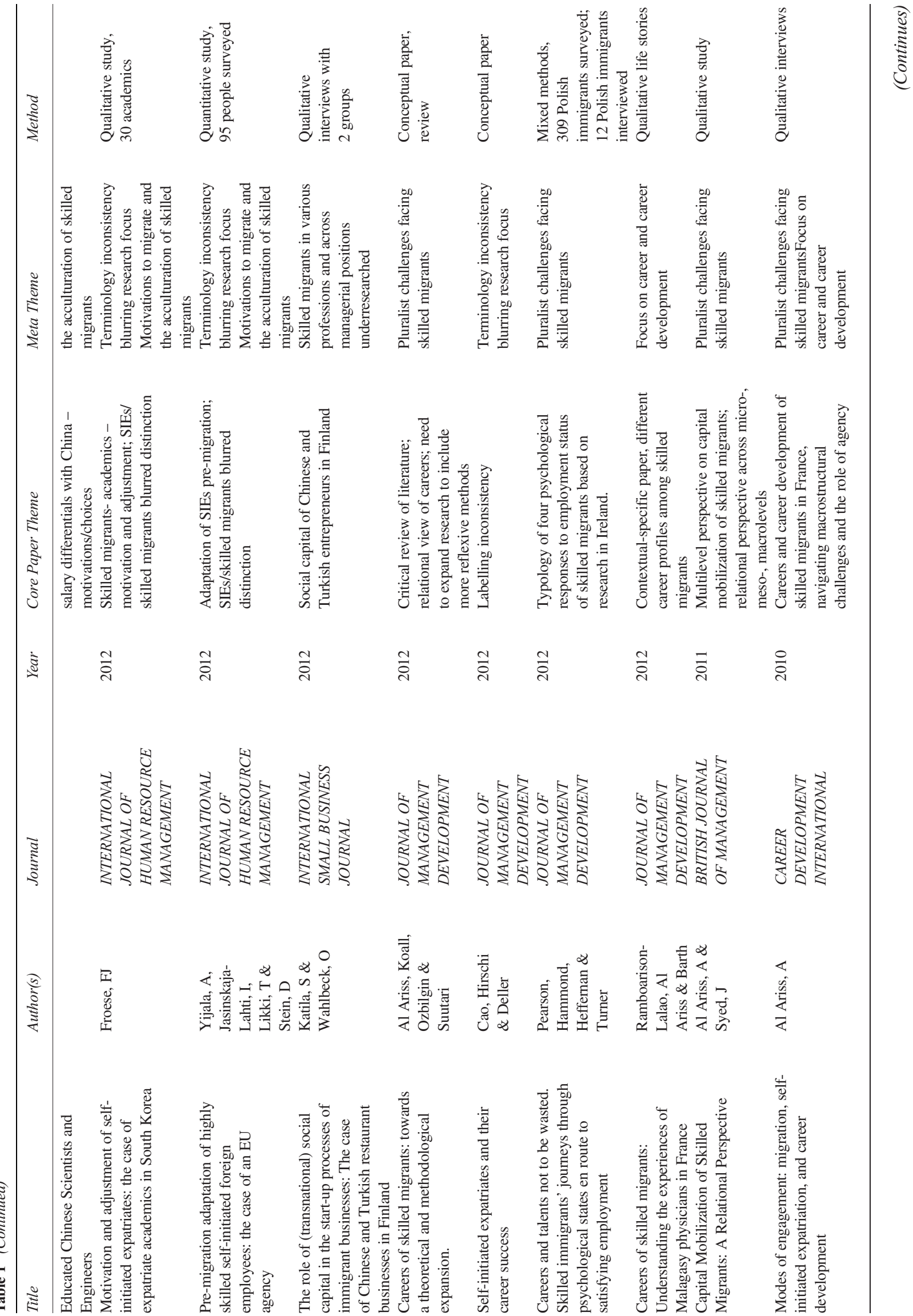




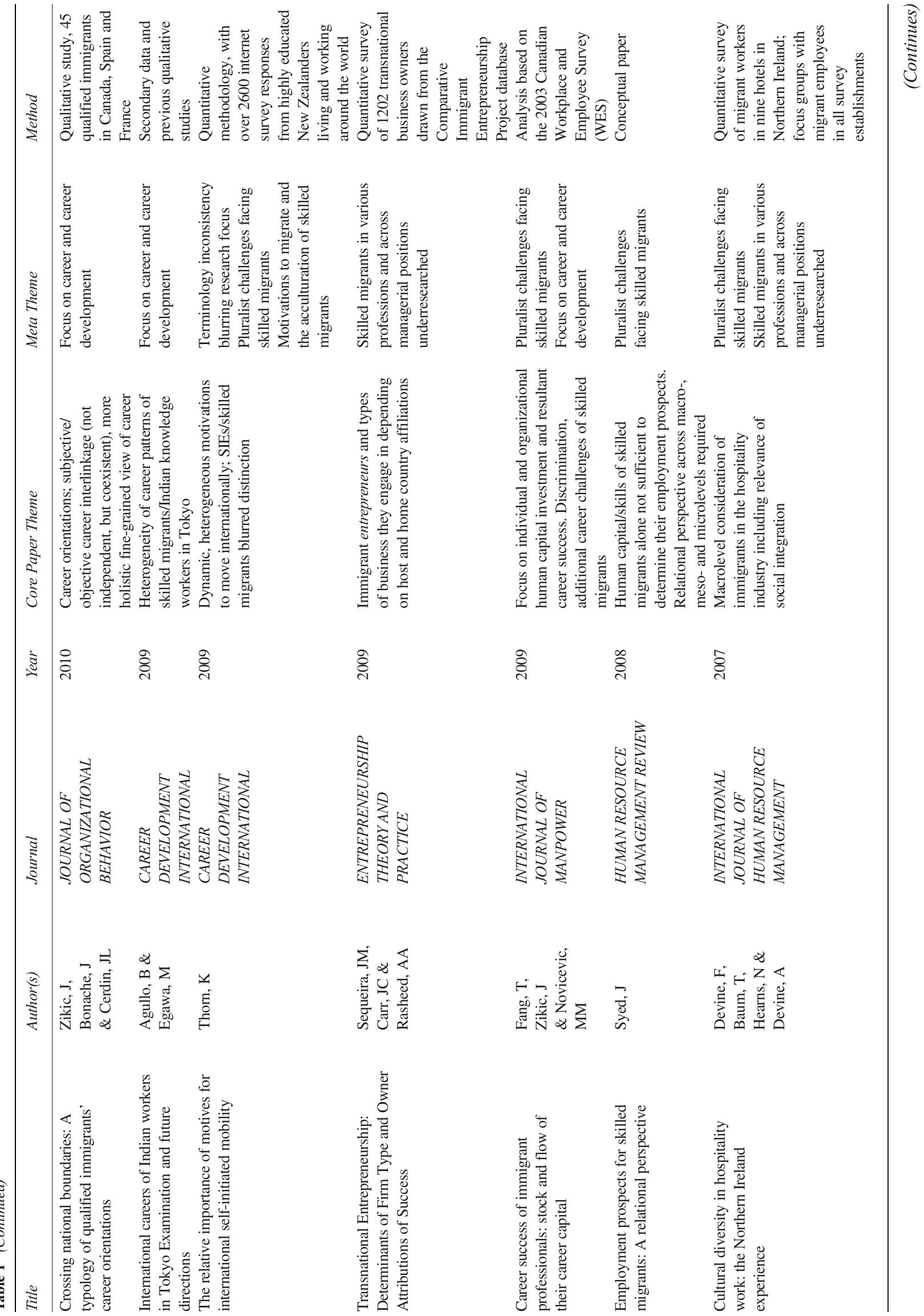




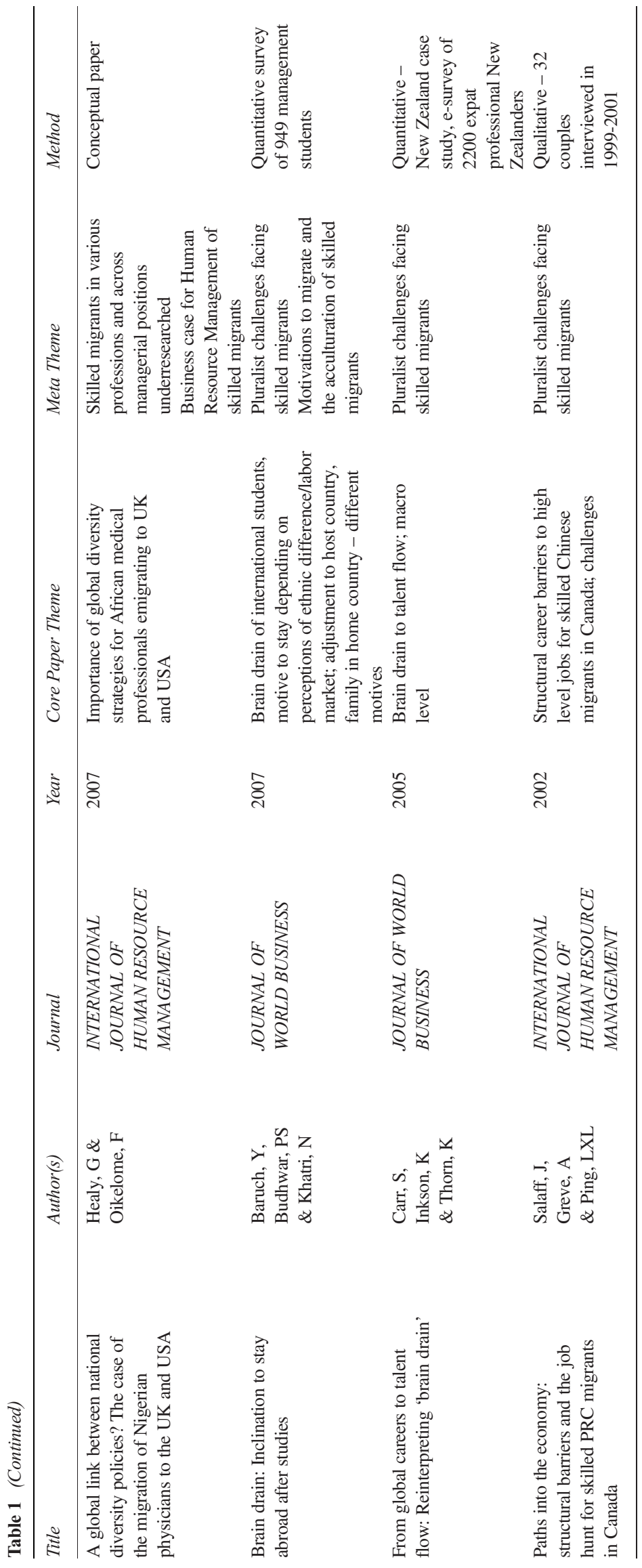


Table 2 Frequency of Articles (on Migration OR Skilled Migrants OR Immigrant Professionals OR and Careers) in Business and Management Studies' Journals (Web of Science Database, 2015)

\begin{tabular}{lcc}
\hline Publication year & Record/count & \% of total count (/52 articles) \\
\hline 2015 & 14 & 26.92 \\
2014 & 9 & 17.31 \\
2013 & 9 & 17.31 \\
2012 & 6 & 11.54 \\
2011 & 2 & 3.85 \\
2010 & 2 & 3.85 \\
2009 & 4 & 7.69 \\
2008 & 1 & 1.92 \\
2007 & 3 & 5.77 \\
2005 & 1 & 1.92 \\
2002 & 1 & 1.92 \\
\hline
\end{tabular}

literature. These themes are considered individually in the Findings and Discussion section of this paper.

Table 2 gives an overview of the number of articles in our SLR since 2000. That table shows that publications relating to skilled migrants' careers in business and management studies have grown in recent years, which is testimony to the growing academic interest in the area of international migrants' careers in the business and management domain.

In addition, it is clear from our review that the journal publishing most in this area is the International Journal of Human Resource Management (at over 32\% of all articles in this domain), followed by Career Development International (at over 8\%). See Table 3. However, it is also evident that interest in this topic is far-reaching, with 20 journals (including top generalist journals such as Journal of International Business Studies and Human Resource Management Journal) having published relevant articles. The widespread interest in the skilled migrant population's career experiences in the host country, with this present review only focused in the business and management publications, highlights its multi- and cross-disciplinary research potential internationally.
Table 1 lists the papers included in this SLR, the theme of the respective paper, our categorization of the paper according to the meta-themes we found, and the research method undertaken in the paper. While each paper adds value in its own right, and we have attempted to summarize some of the main elements of these papers, the purpose of an SLR is to synthesize and group broad themes in order to inform researchers about the existing literature foci and to pinpoint research gaps which could be addressed in future studies. Table 4 presents the six meta-themes we found in our analysis of the literature. While some papers appeared to us to be relevant across more than one theme, we attempted to categorize them, where possible, under one main category/theme. However, for several papers, more than one category was assigned.

We elaborate further upon Table 4, with examples and literature from Table 1, next, in the following section, where we focus on the meta-themes we found during our synthesis of the papers in our SLR (step 5 of the SLR process).

\section{Findings and discussion: core themes arising from the SLR}

The six core themes we found from our review are as follows: terminology inconsistency blurring research focus; pluralist challenges facing skilled migrants; skilled migrants in various professions and across managerial positions underresearched; focus on career/career development; motivations to migrate and the acculturation of skilled migrants; and the business case for human resource management of skilled migrants. We discuss each of these, next.

\section{Terminology inconsistency blurring research focus}

The literature is concerned about the persistent usage of different terminology by different authors in different

Table 3 Primary journals publishing articles on migration, skilled migrants and careers in business and management studies (Web of Science Database, December 2015)

\begin{tabular}{|c|c|c|}
\hline Journal Title & Record Count & $\%$ of total (of the 59 articles) \\
\hline International Journal of Human Resource Management & 19 & 32.203 \\
\hline Journal of Management Development & 5 & 8.474 \\
\hline Career Development International & 5 & 8.474 \\
\hline Journal of World Business & 3 & 5.084 \\
\hline European Management Journal & 2 & 3.389 \\
\hline Human Resource Management Review & 2 & 3.389 \\
\hline International Entrepreneurship and Management Journal & 2 & 3.389 \\
\hline
\end{tabular}

With the following journals having published one article in this space between 2000-2015 and representing 1.694\% respectively of publications here: Administrative Science Quarterly, British Journal of Management, Business and Society, Entrepreneurship Theory and Practice, Human Resource Management Journal, International Journal of Manpower, International Small Business Journal, Journal of Business Ethics, Journal of International Business Studies, Journal of International Management, Journal of Marketing Research, Journal of Organizational Behavior, Strategic Entrepreneurship Journal 


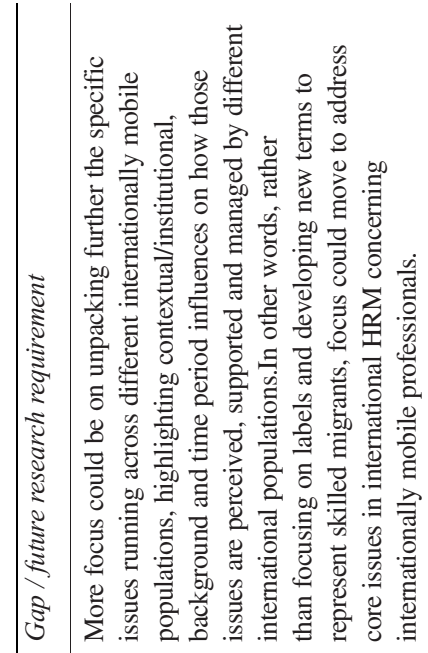

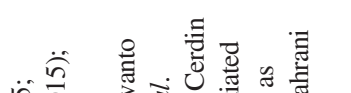

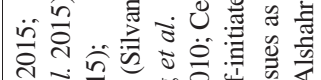
उ उ ช

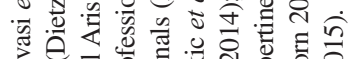

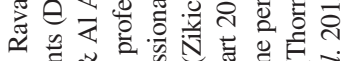

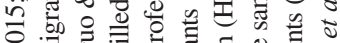

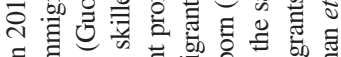

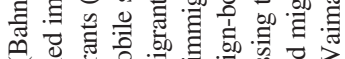

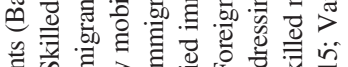

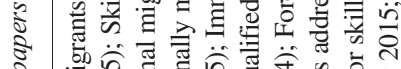

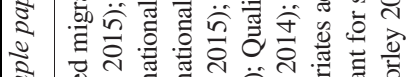
产 चु

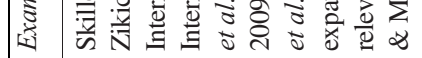

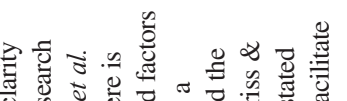

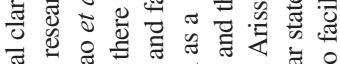

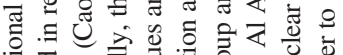

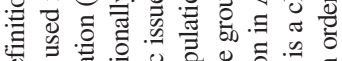
के

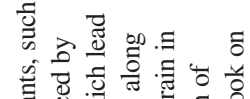

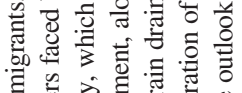

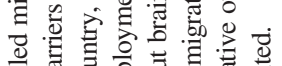

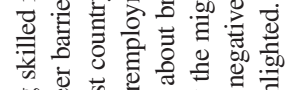

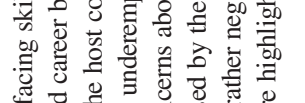

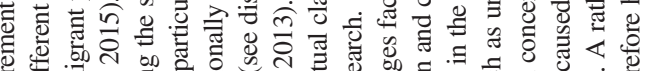

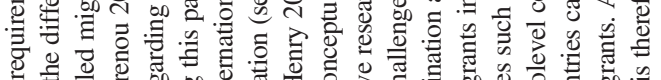

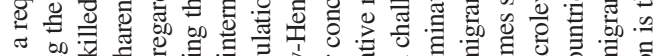

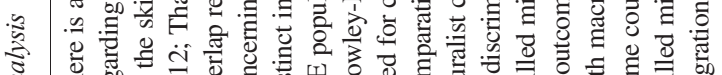

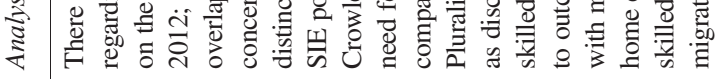

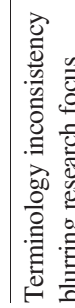

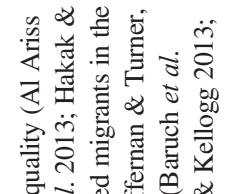

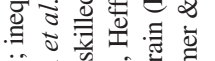

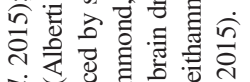

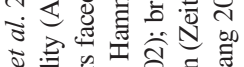

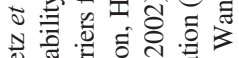

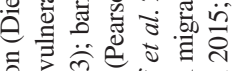

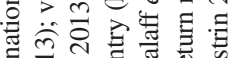

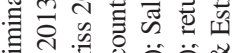

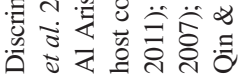

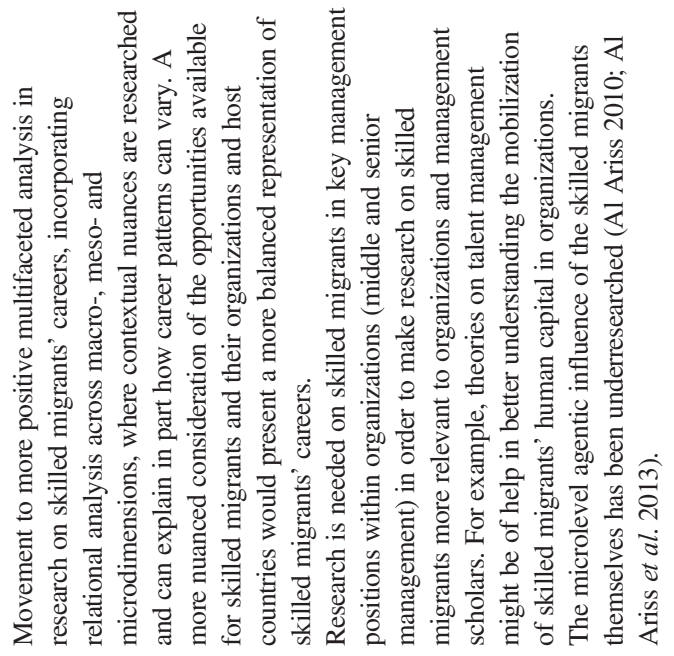

范

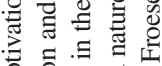

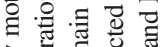

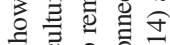

范

㦴 $\overrightarrow{0}$

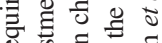

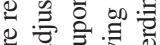

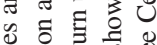

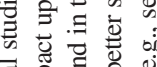

ป ․․․

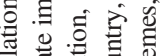

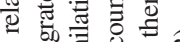

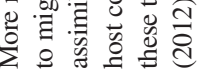

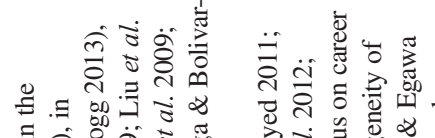

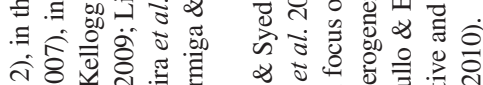

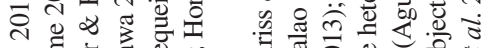

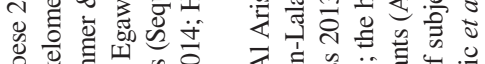

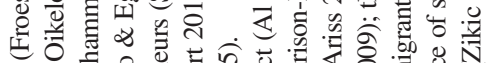

.

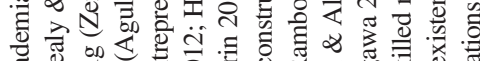

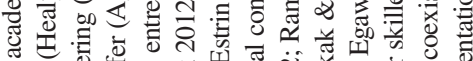

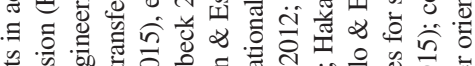

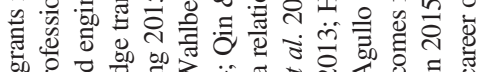

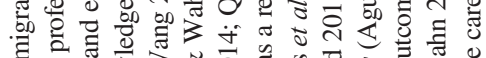

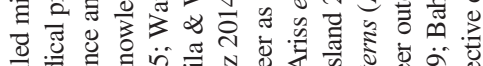

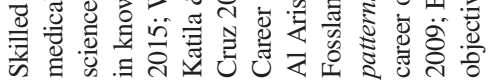

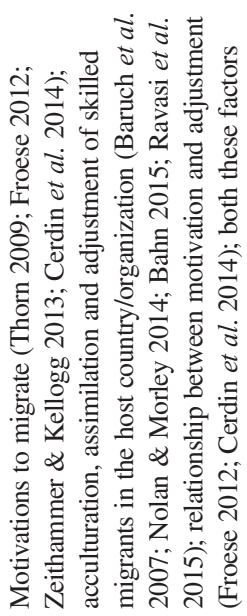

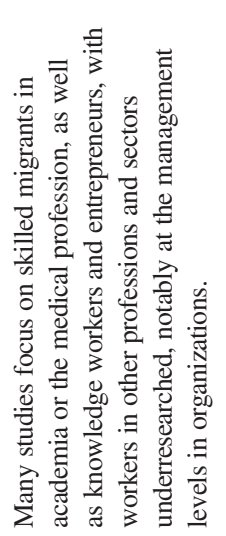

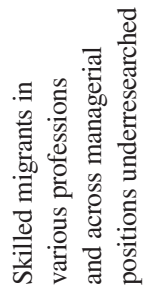

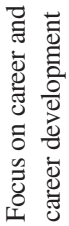

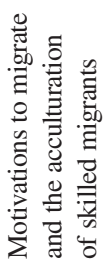

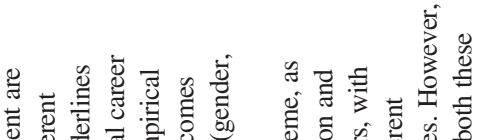

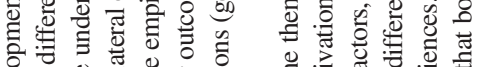

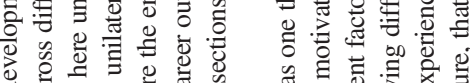

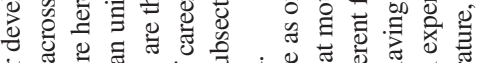

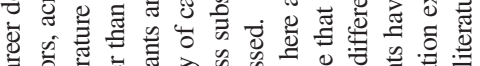

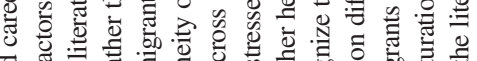

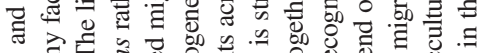

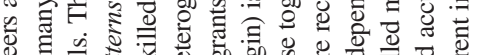

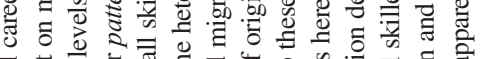

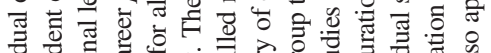

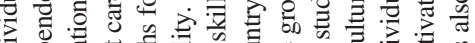

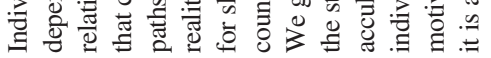


papers when seemingly presenting studies on the same population (Tharenou 2015). In our own review, skilled migrants (e.g., Bahn 2015), skilled immigrants (Dietz et al. 2015), international migrants (Guo \& Al Ariss 2015), internationally mobile skilled professionals (Silvanto et al. 2015), qualified immigrants (e.g., Zikic et al. 2010; Cerdin et al. 2014), immigrant professionals (Fang et al. 2009) and foreign-born [professionals] (Hart 2014) all appear to be analogous and were utilized in papers returned from our search strings. Using these different terms to represent the same population has resulted in a lack of conceptual clarity and is confusing unless clear distinctions between these terms exist and are delineated. Tharenou (2015) has recently highlighted the need for rigor in research on different international worker categories, with her review showing overlap in studies and lack of clarity in many articles with regards to the population under investigation. In our own research, the different terms used to describe the same population resulted in extending the search strings required in conducting the SLR. For further reviews and comparative studies, it could result in some research being excluded due to the lack of terminology uniformity in research on skilled migrants. This highlights the need for conceptual clarity and its importance in assisting the empirical investigation of phenomena and for advancing applied research (Suddaby 2010). Tharenou's (2015) recent paper focuses on the methodological concerns which arise due to the lack of conceptual clarity regarding the different terminology being utilized by different researchers in this area.

It was evident in our review, that even though we did not include 'self-initiated expatriate' (SIE) in our search string for this SLR, some papers were returned due to their usage of the term 'migrant' in their title or abstract or paper, confirming the lack of concept clarity here. Despite our SLR's focus on skilled migrants, the blurring of research boundaries and the extant literature's inherent assumptions concerning SIEs and skilled migrants were covered in a number of the papers returned, such as Cao et al. (2012); Al Ariss and Crowley-Henry (2013); Andresen et al. (2014); and Cerdin and Selmer (2014) ; Alshahrani and Morley (2015). Dickmann and Baruch (2011: 125), for instance, group both 'immigration and self-initiated foreign work' together in recognition that:

Having immigrated, some foreign individuals aim to stay for good. But the reality means that sometimes those who planned to come for a short time stay longer, even permanently. Others who planned to stay a lifetime might decide to return or move on due to unfulfilled expectations or plans

However, our purposeful exclusion of SIEs from the SLR search string ensured the papers returned were relevant to our area of concern (skilled migrants) and were 
focused on research areas specific to skilled migrants and their careers. We did not seek out comparative studies or studies focusing on SIEs (see Doherty 2013 for a literature review on SIEs), but rather, our focus was on considering literature specific to skilled migrants' careers, and that was our intent when using the search strings we did.

It is evident that similar issues are pertinent for both skilled migrants and SIEs, with the research in this space and the issues being studied running across these populations. In our review, for instance, we include Vaiman et al.'s (2015) paper on the effective utilization of SIEs for global talent management, which returned from our database search string, even though 'SIE' was not included in the search string. We retained it in our SLR analysis because we felt that similar concerns with global talent management would equally apply for organizations and their effective utilization of skilled migrants for global talent management. Similarly, Alshahrani and Morley's (2015) research which found different mobility patterns between organization-assigned expatriates and self-initiated expatriates is also relevant for researchers on skilled migrants' career patterns.

We conclude that while much effort seems to be given to researching and distinguishing between different internationally mobile populations, perhaps more focus could be on unpacking further the common issues facing internationally mobile professionals, where the heterogeneity of multilevel influences impacting on international careers is apparent. In this way, while common issues are being researched, the degree to which those respective issues are pertinent to different internationally mobile populations due to context, background and period in time could be qualified. Furthermore, future research in this area could seek to combine the existing terms describing skilled migrants by analyzing in depth the different research studies which use different terms, and possibly presenting a table where clear differences in the populations under consideration are provided for researchers' reference.

\section{Pluralist challenges facing skilled migrants}

The second theme from our analysis of the literature in our review notes the tendency to present a unidimensional portrait of skilled migrants' careers, where discrimination (Dietz et al. 2015), inequality (Al Ariss et al. 2013), vulnerability (Alberti et al. 2013; Hakak \& Al Ariss 2013) and the macro-, meso- and microlevel barriers faced by skilled migrants in the host country (Hakak \& Al Ariss 2013), such as underemployment (Salaff et al. 2002; Pearson et al. 2012) and institutional barriers (Bjerregaard 2014), are discussed. The literature also contains macrolevel concerns about brain drain in home countries caused by skilled migration (Baruch et al. 2007; ) and a focus on return migration (Zeithammer \& Kellogg 2013; Qin \&
Estrin 2015; Wang 2015), rather than a promotion of international talent flows, as suggested by Carr et al. (2005). Overall the literature portrays migration in a negative light with migrants, in general, experiencing poor career outcomes (Fang et al. 2009), such as underemployment and talent wastage (RamboarisonLalao et al. 2012). The SLR also exposed a gap in the study of the agency of skilled migrant workers with skilled migrants assumed to have little or no ability to overcome career barriers (Al Ariss et al. 2012). We suggest that future research on skilled migrants' careers should include a more positive multifaceted analysis, incorporating a relational inquiry across macro-, meso- and micro dimensions. Such an approach can aid in explaining the variation in career patterns for skilled migrants from different home countries in different host country contexts. A more nuanced consideration of the opportunities available for skilled migrants would present a more balanced representation of skilled migrants' careers as, despite the negativity of the literature, there are migrants who have careers at top managerial levels, which can be objectively assessed as successful (Davoine \& Ravasi 2013). Individual success stories, ethnographic diaries and research documenting the challenging but often rewarding pathway to career success at objective and subjective levels would be welcomed here. Qualitative research, including interviews, case studies and ethnographic studies would be most suitable here.

\section{Skilled migrants in various professions and across managerial positions underresearched}

Many studies in our review focus on skilled migrants in particular professions, such as those in academia (Froese 2012) or the medical profession (Healy \& Oikelome 2007), as well as knowledge workers (Agullo \& Egawa 2009; Liu et al. 2015; Wang 2015), scientists and engineers (Lewin \& Zhong 2013; Zeithammer \& Kellogg 2013), and entrepreneurs (Sequeira et al. 2009; Katila \& Wahlbeck 2012; Hart 2014; Hormiga \& Bolivar-Cruz 2014; Qin \& Estrin 2015). Other studies focus on migrants in a particular sector (such as the hospitality sector, Devine et al. 2007). Skilled migrants in other professions and sectors are underresearched. A notable gap here is the dearth of studies on skilled migrants at the managerial level within organizations, which would be of considerable relevance in business and management studies (Davoine \& Ravasi 2013).

We suggest that future research on the competitive advantages of hiring and mobilizing talents of skilled migrants in organizations is essential if the skilled migrant population is to receive focus in business and management studies. Without empirical research on the management levels within organizations, where skilled migrants may occupy top, senior and middle management 
positions, the relevance of the population to organizations will remain under developed.

\section{Focus on career and career development}

Our fourth theme is not surprising given that our SLR concentrates on skilled migrants' careers. In our analysis, it is widely accepted in the literature that careers and career development are dependent on many factors, across different relational levels (Syed 2008; Al Ariss \& Syed 2011; Hakak \& Al Ariss 2013), underlining that career patterns (Agullo \& Egawa 2009) rather than predefined career paths for skilled migrants are a more realistic outcome in research in this space. The heterogeneity of career outcomes for skilled migrants across subsections of this population (including gender, Cooke et al. 2013) is stressed (see also, Agullo \& Egawa 2009; Bahn 2015), where subjective and objective career orientations are not independent, but rather coexist (Zikic et al. 2010).

However, despite acknowledgement of the multilevel, relational influence on career and career development across the macro-country, meso-organization and microindividual domains (Rodriguez \& Scurry 2014), the micro-level agentic influence of the skilled migrants themselves has been underresearched (Al Ariss 2010; $\mathrm{Al}$ Ariss et al. 2013). It is at this level, 'the human face of migration' (Fang et al. 2009), where the individual career experiences of the population of skilled migrants can be unearthed and then analyzed in light of organizational and national contextual factors. For example, more research is needed on the way skilled migrants succeed in their careers, the strategies that they deploy, and the networks that they mobilize in their careers. There is also a dearth in the literature on how skilled migrants face and cope with barriers to their career development in the host country (Fossland 2013). Capital and capital mobilization are two issues in this area of the literature with human capital being the main form of capital used to study migrant careers (Al Ariss \& Syed 2011). This has created a gap in the knowledge of migrant career development because human capital lacks comprehensive qualitative understanding and has a narrow focus, ignoring the other forms of capital utilized by migrants during their careers (Al Ariss \& Syed 2011). Therefore, research exploring capital mobilization and agency of skilled migrants is required to support knowledge development on particular career theory and career development factors which are relevant to the population of skilled migrants.

\section{Motivations to migrate and the acculturation of skilled migrants}

The fifth theme which features in our review considers both skilled migrants' motivations to migrate (Thorn
2009; Froese 2012; Zeithammer \& Kellogg 2013; Cerdin et al. 2014), and the acculturation, assimilation and adjustment of skilled migrants in the host country/organization (Baruch et al. 2007; Yijala et al. 2012; Nolan \& Morley 2014; Bahn 2015; Ravasi et al. 2015). We group these themes together here in our analysis, since these factors combined play an influential role in the skilled migrant's decision and ultimate choice to remain in the host country (Baruch et al. 2007) and to continue an international career. The relationship between motivation to migrate and eventual adjustment has been proven (Froese 2012; Cerdin et al. 2014). Cerdin et al. (2014) found that qualified immigrant success is positively connected to their motivation to integrate in their host country, which in turn is connected to their original motivations for immigrating.

However, further relational studies on how motivations to migrate impact upon adjustment, acculturation and assimilation are needed in order to unpack decision patterns of skilled migrants to remain in the host country and to further prove the interconnected nature of these themes. Given the heterogeneity of the motivations to migrate, such as influences of a vocational, cultural or economic nature, and of adjustment factors, such as cultural (Ravasi et al. 2015) or psychological (Hakak \& Al Ariss 2013), empirical evidence on the following would be invaluable: migrants' motivations to move internationally, adjustment and adaptation to their new position in the host country, and decision to remain in the host country. Such evidence would enable organizations to design and implement relevant programs and supports to recruit and retain skilled migrants in the long term (Cao et al. 2012).

\section{Business case for human resource management of skilled migrants}

Our final overarching theme focuses on the benefits of diversity and why human resource management, as a discipline, should be interested in understanding skilled migrants' careers in more detail. Ng and Metz (2015) present the case for multiculturalism for Canada and Australia, espousing the policies that promote multiculturalism and how multiculturalism relates to competitiveness at country level. At organizational level, Liu et al. (2015) research highly skilled migrants and knowledge transfer between organizations in different countries. Zikic (2015) exhibits how intelligent career theory and the resource-based view of diversity can be utilized to enlighten HRM practitioners and organizations on how best to leverage the career capital of their skilled migrant employees for competitive advantage. Guo and Al Ariss (2015) also call for better understanding on the human resource management of skilled migrants. 
Similarly, Podsiadlowski and Reichel (2014) link macro- and meso-level analysis in order to show that social reasons and corporate social responsibility are prioritized by organizations when considering action programs for ethnic minorities. Bahn's (2015) recent study promotes the organizational advantages of enhancing the well-being of temporary skilled migrants, and suggests assimilation strategies at the HRM/organizational level to support the retention of skilled migrants.

Further studies on the relevance of skilled migrants for organizations and human resource management in enabling superior performance through the effective and strategic utilization of skilled migrants are needed. In the domain of international strategic human resource management, the effective use of internationally mobile professionals is required (Vaiman et al. 2015).

Studies researching the link between business outcomes and the HRM strategies supporting skilled migrants in organizations would contribute to changing the portrayal of skilled migrants' careers as predominately challenging to advantageous. A closer alignment between research on skilled migrants and the relevance for organizations and businesses is required. For instance, future research could consider business performance outcomes (e.g., financial reports) as well as the corresponding organization's human resource management policies supporting international workers in order to determine correlations. Detailed case studies, with access to company reports and financial statements, would be recommended.

\section{Future research direction}

This paper has considered prevailing themes on skilled migrants' careers across business and management publications in order to present a portrait of the existing literature on skilled migrants' careers to both academic and practitioner audiences. The objective was to amass and analyze existing knowledge on skilled migrants' careers, from which gaps could be identified. Those gaps would then serve as the basis for a research agenda of

Table 5 Future research agenda

\begin{tabular}{|c|c|}
\hline Theme & Research agenda/requirements \\
\hline $\begin{array}{l}\text { Clarifying the terminology and concepts on } \\
\text { skilled migration Focus on core relevant issues }\end{array}$ & $\begin{array}{l}\text { A detailed analysis across studies using different terms to consider the skilled migrant } \\
\text { population in order to be able to provide (if existing) clear distinctions and delineation of the } \\
\text { specific population to which the different terms apply. In our review, we consider many of } \\
\text { these terms to be analogous, but further analysis and confirmation would facilitate } \\
\text { conceptual clarity in future research.To prevent future research becoming cumbersome in trying } \\
\text { to distinguish between the terminology variations for skilled migrants and to undertake } \\
\text { comparative research in this area, research could focus more on relevant issues (such as } \\
\text { discrimination, career success, etc.) impacting all internationally mobile professionals } \\
\text { (e.g., organization-assigned, SIE and skilled migrant), presenting the heterogeneity of factors } \\
\text { under respective issues which may determine the outcome for the individual and the organization. }\end{array}$ \\
\hline $\begin{array}{l}\text { Focus on the more positive outcomes of } \\
\text { skilled migration }\end{array}$ & $\begin{array}{l}\text { Movement to more multifaceted analysis in research on skilled migrants' careers, incorporating } \\
\text { relational analysis across macro-, meso- and microdimensions. A more positive consideration of } \\
\text { the opportunities available for skilled migrants and their organizations and host countries would } \\
\text { present a more complete representation of skilled migrants' careers. Success stories representing } \\
\text { skilled migrants who have attained positive career outcomes from their migration in the } \\
\text { business and management space would be welcome research here. }\end{array}$ \\
\hline $\begin{array}{l}\text { Enlarging focus in empirical research to } \\
\text { include underrepresented professions and top } \\
\text { managerial positions }\end{array}$ & $\begin{array}{l}\text { Research is required on skilled migrants at the managerial level within organizations, which } \\
\text { would be of considerable relevance in business and management studies. Recent research on } \\
\text { foreign CEOs in France, Germany, Great Britain and Switzerland (see Davoine \& Ravasi } \\
\text { 2013) is a good start. }\end{array}$ \\
\hline $\begin{array}{l}\text { More focus on career research and career } \\
\text { development of skilled migrants }\end{array}$ & $\begin{array}{l}\text { Further research exploring capital mobilization (Al Ariss \& Syed 2011) and agency of skilled } \\
\text { migrants (Al Ariss 2010; Al Ariss et al. 2013) is required to support knowledge development } \\
\text { on particular career theory and career development factors which are relevant to the population } \\
\text { of skilled migrants. }\end{array}$ \\
\hline $\begin{array}{l}\text { Uncovering the relationship between } \\
\text { motivation and adjustment, also acculturation, } \\
\text { assimilation and decision to remain in a host } \\
\text { country }\end{array}$ & $\begin{array}{l}\text { Further relational studies on how motivations to migrate impact upon adjustment, acculturation } \\
\text { and assimilation are needed in order to unpack decision patterns of skilled migrants to remain in } \\
\text { the host country and to further prove the interconnected nature of these themes. Given the } \\
\text { heterogeneity of motivations and adjustment factors, empirical studies incorporating motivations } \\
\text { to expatriate, adjustment to new positions (in the host country) and decision to remain in the host } \\
\text { country would be invaluable for organizations in understanding and implementing relevant } \\
\text { supports to retain their skilled migrant talent. }\end{array}$ \\
\hline $\begin{array}{l}\text { Depicting a business case in terms of } \\
\text { organizational advantages of effective } \\
\text { utilization and talent management of skilled } \\
\text { migrants }\end{array}$ & $\begin{array}{l}\text { Detailed organizational research (such as via organizational case studies) on human resource } \\
\text { practices concerning skilled migrants in organizations, the effective utilization of skilled } \\
\text { migrants in organizations, and the corresponding business outcomes (profitability, } \\
\text { performance, quality) is required in order to underscore the relevance for organizations and } \\
\text { businesses of skilled migrants in their employment. }\end{array}$ \\
\hline
\end{tabular}


particular interest for scholars in management and organization studies. Further research in this area would also be beneficial to human resource management practitioners and organizations in sharing the career patterns of skilled migrants, with the multilevel, relational influences, which are important for organizations to understand when developing policies to support skilled migrant retention.

Table 5 summarizes the future research requirements concerning the careers of skilled migrants, as unearthed in our SLR, and as discussed briefly under each of the respective themes above.

\section{Limitations of the Study}

A limitation of all SLRs is that the searches conducted are only as good as the search strings that are established. As outlined earlier in the paper, we included terms in our original search string in order to return more articles concerned with skilled migrants' careers in business and management studies. We also relied on our judgment to exclude articles we felt did not meet our research objective (to share existing research on skilled migrants' careers), and to include those that did. Other researchers may have made different choices.

Similarly, the synthesis (Petticrew \& Roberts 2006) of the six core themes portrayed in the SLR were determined collaboratively by the researchers. Other research groups or researchers may have focused on different themes. Nonetheless, the SLR process we followed is replicable and other researchers may undertake a similar review, which would then facilitate a comparative analysis of the corresponding findings with our review, further informing this research topic.

In line with this special issue, our review focused on publications in the business and management discipline. Wider reviews across disciplines would uncover themes which could have the potential to be researched further through cross- and multidisciplinary studies.

\section{Conclusions}

In order to present a portrait of current literature regarding skilled migrants' careers, we researched existing studies and literature in the business and management domain, using the Web of Science database's Social Science Citation Index. The systematic literature review (SLR) process that we have adopted offers a scientific and reliable alternative to the traditional literature review, an alternative that seeks to reduce bias in a fully accountable process (Tranfield et al. 2003; Pittaway et al. 2004). This research process has shown that the SLR is a rigorous, comprehensive process with which to unpick core topics and themes. Systematic literature searches enable comparative literature research to be conducted within and across disciplines. It facilities the ability to highlight research undertakings within management and business studies, which can then lead to identifying gaps and research plans.

The paper contributes to the management and organization studies literatures in two important ways: first, in systematically identifying the predominant existing themes regarding skilled migrants, and, second, in underlining the gaps in the literature and research in this area through a proposed research agenda. This paper contributes to this special issue by consolidating research on skilled migrants' careers to date, demonstrating how the careers of skilled migrants are considered in the literature, and presenting a research agenda to fill the gaps in the existing research.

The resultant 52 papers of our review were thematically analyzed under six broad headings, as shown in Table 4 and summarized subsequently. The myriad of terms used to denote skilled migrants was found to be a deterrent to comparative research opportunities in this space. We therefore called on researchers to analyze any conceptual differences between the variety of terms used which we believe to be analogous with skilled migrants and to share the distinctions with the wider research community. Without such delineation or consensus that the terms represent the same skilled migrant population, future research studies in this area are in jeopardy of lacking comparative possibilities. We also suggest that a current research gap in this domain is a focus on contrasting different internationally mobile populations, rather than highlighting the common issues faced to varying degrees by different internationally mobile groups.

Given the focus on the challenges encountered by skilled migrants in the host country, we suggest a more balanced representation of both opportunities and challenges across relational, multilevel research analyses, particularly focusing on the micro-individual level concerning capital mobilization and agency of skilled migrants in terms of their own career outcomes and development. Thus there is a need for studies that go beyond the negative portrayal of skilled migrants, as this focus lacks the depth of reasoning and agency behind many skilled migrants careers (Syed 2008).

Also in the domain of skilled migration, studies need to be conducted with skilled migrant business professionals in order to garner information on employees at the managerial levels in organizations, in terms of organizational challenges and supports required. Research on skilled migrants within business organizations would aid human resource practitioners in understanding the particular challenges faced by skilled migrants and in being able to better support their retention in the organization. 
Finally, in order to prove the business case for diversity and how the effective utilization of skilled migrants can lead to superior competitive performance and advantage, empirical evidence and case study research in organizations is required. In testing how skilled migrants in organizations impact on organizational performance, with their utilization aligned with business strategy and practices, and supported with HR policies and programs, a more positive consideration of skilled migrants' careers in organizations may be realized. All of our further research suggestions are portrayed in Table 5. Our review presents the current portrayal of skilled migrants in business and management studies, and it also outlines the strategic potential and relevance for organizations in advancing research on skilled migrants in terms of their effective utilization in organizations.

\section{References}

Agullo, B. and M. Egawa, 2009, "International careers of Indian workers in Tokyo Examination and future directions". Career Development International, 14: 148-168.

Al Ariss, A., 2010, "Modes of engagement: migration, selfinitiated expatriation, and career development". Career Development International, 15: 338-358.

Al Ariss, A. and M. Crowley-Henry, 2013, "Self-initiated expatriation and migration in the management literature: Present theorizations and future research directions". Career Development International, 18: 78-96.

Al Ariss, A., I. Koall, M. F. Ozbilgin and V. Suutari, 2012, "Careers of skilled migrants: Towards a theoretical and methodological expansion". Journal of Management Development, 31: 92-101.

Al Ariss, A. and J. Syed, 2011, "Capital mobilization of skilled migrants: A relational perspective". British Journal of Management, 22: 286-304.

Al Ariss, A., J. Vassilopoulou, M. F. Ozbilgin and A. Game, 2013, "Understanding career experiences of skilled minority ethnic workers in France and Germany". International Journal of Human Resource Management, 24: 1236-1256.

Alberti, G., J. Holgate and M. Tapia, 2013, "Organising migrants as workers or as migrant workers? Intersectionality, trade unions and precarious work". International Journal of Human Resource Management, 24: 4132-4148.

Alshahrani, S. T. and M. J. Morley, 2015, “Accounting for variations in the patterns of mobility among conventional and self-initiated expatriates". International Journal of Human Resource Management, 26: 1936-1954.

Andresen, M., F. Bergdolt, J. Margenfeld and M. Dickmann, 2014, "Addressing international mobility confusion developing definitions and differentiations for self-initiated and assigned expatriates as well as migrants". International Journal of Human Resource Management, 25: 2295-2318.

Arksey, H. and L. O'Malley, 2005, "Scoping studies: Towards a methodological framework". International Journal of Social Research Methodology, 8: 19-32.
Bahn, S., 2015, "Managing the well-being of temporary skilled migrants". International Journal of Human Resource Management, 26: 2102-2120.

Baruch, Y., P. S. Budhwar and N. Khatri, 2007, "Brain drain: Inclination to stay abroad after studies". Journal of World Business, 42: 99-112.

Bjerregaard, T., 2014, "Engaging institutions in global careers: Highly skilled self-initiated expatriates' journeys through a Nordic welfare state". European Management Journal, 32: 903-915.

Borjas, G. J., 2001, "Does immigration grease the wheels of the labour market?'. Brookings Papers on Economic Activity, 1: 69-119.

Cao, L., A. Hirschi and J. Deller, 2012, "Self-initiated expatriates and their career success". Journal of Management Development, 31: 159-172.

Carr, S. C., K. Inkson and K. Thorn, 2005, "From global careers to talent flow: Reinterpreting 'brain drain'". Journal of World Business, 40: 386-398.

Cerdin, J.-L., M. A. Dine and C. Brewster, 2014, "Qualified immigrants' success: Exploring the motivation to migrate and to integrate". Journal of International Business Studies, 45: 151-168.

Cerdin, J.-L. and J. Selmer, 2014, "Who is a self-initiated expatriate? Towards conceptual clarity of a common notion". International Journal of Human Resource Management, 25: 1281-1301.

Cooke, F. L., J. Zhang and J. Wang, 2013, "Chinese professional immigrants in Australia: A gendered pattern in (re)building their careers". International Journal of Human Resource Management, 24: 2628-2645.

Davoine, E. and C. Ravasi, 2013, "The relative stability of national career patterns in European top management careers in the age of globalisation: A comparative study in France/Germany/Great Britain and Switzerland". European Management Journal, 31: 152-163.

Denyer, D. and D. Tranfield, 2009. "Producing a systematic review". In Buchanan D. A. and A. Bryman (eds.), The Sage handbook of organisational research methods. London: Sage, pp 671-689.

Devine, F., T. Baum, N. Hearns and A. Devine, 2007, "Cultural diversity in hospitality work: the Northern Ireland experience". International Journal of Human Resource Management, 18: 333-349.

Dickmann, M. and Y. Baruch, 2011. Global careers. New York: Routledge.

Dietz, J., C. Joshi, V. M. Esses, L. K. Hamilton and F. Gabarrot, 2015, "The skill paradox: Explaining and reducing employment discrimination against skilled immigrants". International Journal of Human Resource Management, 26: 1318-1334.

Doherty, N., 2013, "Understanding the self-initiated expatriate: A review and directions for future research". International Journal of Management Reviews, 15: 447-469.

Fang, T., J. Zikic and M. M. Novicevic, 2009, "Career success of immigrant professionals: Stock and flow of their career capital". International Journal of Manpower, 30: 472-488.

Fossland, T., 2013, "Negotiating future careers - a relational perspective on skilled migrants' labour market participation". 
Journal of Management Development, 32: 193-203.

Froese, F. J., 2012, "Motivation and adjustment of self-initiated expatriates: The case of expatriate academics in South Korea". International Journal of Human Resource Management, 23: 1095-1112.

Guo, C. and A. Al Ariss, 2015, "Human resource management of international migrants: Current theories and future research: Introduction". International Journal of Human Resource Management, 26: 1287-1297.

Hakak, L. T. and A. Al Ariss, 2013, "Vulnerable work and international migrants: A relational human resource management perspective". International Journal of Human Resource Management, 24: 4116-4131.

Hart, D. M., 2014, "Founder nativity, founding team formation, and firm performance in the US high-tech sector". International Entrepreneurship and Management Journal, 10: 1-22.

Healy, G. and F. Oikelome, 2007, "A global link between national diversity policies? The case of the migration of Nigerian physicians to the UK and USA". International Journal of Human Resource Management, 18: 1917-1933.

Hormiga, E. and A. Bolivar-Cruz, 2014, "The relationship between the migration experience and risk perception: A factor in the decision to become an entrepreneur". International Entrepreneurship and Management Journal, 10: 297-317.

Iredale, R., 1999, "The need to import skilled personnel: Factors favouring and hindering its international mobility". International Migration, 37: 89-123.

Katila, S. and O. Wahlbeck, 2012, "The role of (transnational) social capital in the start-up processes of immigrant businesses: The case of Chinese and Turkish restaurant businesses in Finland". International Small Business Journal, 30: 294-309.

Lewin, A. Y. and X. Zhong, 2013, "The evolving diaspora of talent: A perspective on trends and implications for sourcing science and engineering work". Journal of International Management, 19: 6-13.

Liu, X., L. Gao, J. Lu and Y. Wei, 2015, "The role of highly skilled migrants in the process of inter-firm knowledge transfer across borders". Journal of World Business, 50: 56-68.

Nolan, E. M. and M. J. Morley, 2014, "A test of the relationship between person-environment fit and cross-cultural adjustment among self-initiated expatriates". International Journal of Human Resource Management, 25: 1631-1649.

Ng, E. and I. Metz, 2015, "Multiculturalism as a strategy for national competitiveness: The case for Canada and Australia". Journal of Business Ethics, 128: 253-266.

Özbilgin, M. F., T. A. Beauregard, A. Tatli and M. P. Bell, 2011, "Work-life, diversity and intersectionality: A critical review and research agenda". International Journal of Management Reviews, 13: 177-198.

Pearson, J., M. Hammond, E. Heffernan and T. Turner, 2012, "Careers and talents not to be wasted. Skilled immigrants' journeys through psychological states en route to satisfying employment". Journal of Management Development, 31: 102-115.

Petticrew, M. and H. Roberts, 2006. Systematic reviews in the social sciences. A practical guide. Oxford: Blackwell publishing.

Pittaway, L., M. Robertson, K. Munir, D. Denyer and A. Neely, 2004, "Networking and innovation: A systematic review of the evidence". International Journal of Management Reviews, 5-6: 137-168.
Podsiadlowski, A. and A. Reichel, 2014, “Action programs for ethnic minorities: A question of corporate social responsibility?". Business \& Society, 53: 684-713.

Qin, F. and S. Estrin, 2015, "Does social influence span time and space? Evidence from Indian returnee entrepreneurs". Strategic Entrepreneurship Journal, 9: 226-242.

Ramboarison-Lalao, L., A. Al Ariss and I. Barth, 2012, "Careers of skilled migrants: Understanding the experiences of Malagasy physicians in France". Journal of Management Development, 31: 116-129.

Ravasi, C., X. Salamin and E. Davoine, 2015, "Cross-cultural adjustment of skilled migrants in a multicultural and multilingual environment: An explorative study of foreign employees and their spouses in the Swiss context". International Journal of Human Resource Management, 26: 1335-1359.

Rodriguez, J. K. and T. Scurry, 2014, "Career capital development of self-initiated expatriates in Qatar: Cosmopolitan globetrotters, experts and outsiders". International Journal of Human Resource Management, 25: 190-211.

Salaff, J., A. Greve and L. X. L. Ping, 2002, "Paths into the economy: Structural barriers and the job hunt for skilled PRC migrants in Canada". International Journal of Human Resource Management, 13: 450-464.

Sequeira, J. M., J. C. Carr and A. A. Rasheed, 2009, "Transnational entrepreneurship: Determinants of firm type and owner attributions of success". Entrepreneurship: Theory and Practice, 33: 1023-1044.

Silvanto, S., J. Ryan and Y. McNulty, 2015, “An empirical study of nation branding for attracting internationally mobile skilled professionals". Career Development International, 20: 238-258.

Suddaby, R., 2010, "Construct clarity in theories of management and organization". Academy of Management Review, 35: 346-357.

Syed, J., 2008, "Employment prospects for skilled migrants: A relational perspective". Human Resource Management Review, 18: $28-45$.

Syed, J. and P. Murray, 2009, "Combating the English language deficit: The labour market experiences of migrant women in Australia". Human Resource Management Journal, 19: 413-432.

Tharenou, P., 2015, "Researching expatriate types:The quest for rigorous methodological approaches". Human Resource Management Journal, 25: 149-165.

Tharenou, P., 2015, "Chinese international business graduates: A career dilemma: Repatriate or stay?'. Journal ofManagement \& Organization, 21: 37-59 doi:10.1017/jmo.2014.68

Thorn, K., 2009, "The relative importance of motives for international self-initiated mobility". Career Development International, 14: 441-464.

Tranfield, D., D. Denyer and P. Smart, 2003, "Towards a methodology for developing evidence-informed management knowledge by means of systematic review". British Journal of Management, 14: 207-222.

Vaiman, V., A. Haslberger and C. M. Vance, 2015, "Recognizing the important role of self-initiated expatriates in effective global talent management". Human Resource Management Review, 25: 280-286.

Wang, D., 2015, “Activating cross-border brokerage: Interorganizational knowledge transfer through skilled return migration". Administrative Science Quarterly, 60: 133-176. 
Yijala, A., I. Jasinskaja-Lahti, T. Likki and D. Stein, 2012, "Pre-migration adaptation of highly skilled self-initiated foreign employees: The case of an EU agency". International Journal of Human Resource Management, 23: 759-778.

Zeithammer, R. and R. P. Kellogg, 2013, "The hesitant hai gui: Return-migration preferences of US-educated Chinese scientists and engineers". Journal of Marketing Research, 50: 644-663.

Zikic, J., 2015, "Skilled migrants' career capital as a source of competitive advantage: Implications for strategic HRM". International Journal of Human Resource Management, 26: 1360-1381.

Zikic, J., J. Bonache and J.-L. Cerdin, 2010, “Crossing national boundaries: A typology of qualified immigrants' career orientations". Journal of Organizational Behavior, 31: 667-686 Bottom of Form.

\section{Appendix 1: Search string utilized in Web of Science database, Social Science Citation Index, 9 December 2015}

TOPIC: (migration) $O R$ TOPIC: (skilled migrant) $O R$ TOPIC: (qualified immigrant) OR TOPIC: '(immigrant professional) $A N D$ TOPIC: (career) Analysis: LANGUAGES: (ENGLISH) AND RESEARCH AREAS: (BUSINESS ECONOMICS) AND WEB OF SCIENCE CATEGORIES: (MANAGEMENT OR BUSINESS) AND DOCUMENT TYPES: (ARTICLE) AND [excluding]: SOURCE TITLES: (REVIEW OF AGRICULTURAL ECONOMICS OR NEW TECHNOLOGY WORK AND EMPLOYMENT OR RESEARCH POLICY OR ENTREPRENEURSHIP AND REGIONAL DEVELOPMENT OR JOURNAL OF PRODUCTIVITY ANALYSIS OR DISASTER PREVENTION AND MANAGEMENT OR TRANSFORMATIONS IN BUSINESS ECONOMICS OR COMPUTATIONAL ECONOMICS OR JOURNAL OF DESTINATION MARKETING MANAGEMENT OR INTERNATIONAL JOURNAL OF FORECASTING OR INFORMATION MANAGEMENT OR ACTION RESEARCH OR JOURNAL OF ENVIRONMENTAL ECONOMICS AND MANAGEMENT OR TOTAL QUALITY MANAGEMENT BUSINESS EXCELLENCE OR ELECTRONIC COMMERCE RESEARCH AND APPLICATIONS OR SYSTEMIC PRACTICE AND ACTION RESEARCH OR EMERGING MARKETS FINANCE AND TRADE OR SUPPLY CHAIN MANAGEMENT AN INTERNATIONAL JOURNAL OR SERVICE SCIENCE OR TECHNOVATION OR SCIENCE TECHNOLGY AND SOCIETY OR SYSTEMS RESEARCH AND BEHAVIORAL SCIENCE OR SCIENCE TECHNOLOGY AND SOCIETY OR RESEARCH TECHNOLOGY MANAGEMENT OR SCIENCE AND PUBLIC POLICY OR R D MANAGEMENT OR INTERNATIONAL JOURNAL
OF TECHNOLOGY MANAGEMENT OR QME QUANTITATIVE MARKETING AND ECONOMICS OR REVIEW OF INDUSTRIAL ORGANIZATION OR JOURNAL OF MACROMARKETING OR JOURNAL OF THE OPERATIONAL RESEARCH SOCIETY OR MIS QUARTERLY EXECUTIVE OR JOURNAL OF STRATEGIC INFORMATION SYSTEMS OR MIS QUARTERLY OR INTERNATIONAL JOURNAL OF CONSUMER STUDIES OR JOURNAL OF SERVICE RESEARCH OR MARKETING THEORY OR INFORMATION SYSTEMS RESEARCH OR MARKETING SCIENCE OR INDUSTRIAL AND CORPORATE CHANGE OR MARKETING LETTERS OR JOURNAL OF MARKETING OR EUROPEAN JOURNAL OF OPERATIONAL RESEARCH OR ELECTRONIC COMMERCE RESEARCH OR INTERNATIONAL MARKETING REVIEW OR E M EKONOMIE A MANAGEMENT OR TECHNOLOGY ANALYSIS STRATEGIC MANAGEMENT OR INTERNATIONAL JOURNAL OF RESEARCH IN MARKETING OR TECHNOLOGICAL FORECASTING AND SOCIAL CHANGE OR INTERNATIONAL JOURNAL OF OPERATIONS PRODUCTION MANAGEMENT OR INTERNATIONAL JOURNAL OF MARKET RESEARCH) AND [excluding]: SOURCE TITLES: (INTERNATIONAL JOURNAL OF SHIPPING AND TRANSPORT LOGISTICS OR INTERNATIONAL JOURNAL OF ELECTRONIC COMMERCE OR INTERFACES OR INNOVATION MANAGEMENT POLICY PRACTICE OR INFORMATION TECHNOLOGY MANAGEMENT OR INFORMATION AND ORGANIZATION OR INDUSTRY AND INNOVATION OR INDUSTRIAL MARKETING MANAGEMENT OR IMA JOURNAL OF MANAGEMENT MATHEMATICS OR GEOGRAPHY AND STRATEGY OR CONSUMPTION MARKETS CULTURE OR BUSINESS HISTORY REVIEW OR BUSINESS HISTORY OR ADVANCES IN CONSUMER RESEARCH VOL 30 OR ADVANCES IN CONSUMER RESEARCH) AND [excluding]: SOURCE TITLES: (JOURNAL OF INTERACTIVE MARKETING OR JOURNAL OF INFORMATION TECHNOLOGY OR JOURNAL OF FORECASTING OR JOURNAL OF ELECTRONIC COMMERCE RESEARCH OR JOURNAL OF CONSUMER RESEARCH OR JOURNAL OF CONSUMER AFFAIRS OR JOURNAL OF BUSINESS VENTURING OR INTERNATIONAL TRANSACTIONS IN OPERATIONAL RESEARCH OR SYSTEM DYNAMICS REVIEW OR OPERATIONS RESEARCH OR JOURNAL OF THE ACADEMY OF MARKETING SCIENCE OR JOURNAL OF TECHNOLOGY TRANSFER OR JOURNAL OF ORGANIZATIONAL AND END USER COMPUTING OR JOURNAL OF OPERATIONS MANAGEMENT) 